\title{
PENGEMBANGAN BAHAN AJAR APRESIASI PUISI BERBASIS NILAI BELA NEGARA BAGI MAHASISWA SEMESTER III PENDIDIKAN BAHASA DAN SASTRA INDONESIADI UNIVERSITAS MUHAMMADIYAH PURWOREJO
}

\author{
Nurul Setyorini ${ }^{1}$, Suci Rizkiana ${ }^{2}$ \\ Universitas Muhammadiyah Purworejo \\ nurulsetyorini32@gmail.com \\ qian_rizki@gmail.com
}

\begin{abstract}
ABSTRAK
Tujuan penelitian ini untuk mendeskripsikan tahapan pengembangan bahan ajar apresiasi puisi berbasis nilai bela negara. Desain penelitian ini merupakan penelitian R\&D (Research and Development). Model pengembangan bahan ajar terdapar lima tahap, tahap pertama analisis kebutuhan bahan ajar bagi mahasiswa, tahap kedua perencanaan prototype bahan ajar, tahap ketiga pengembangan produk awal menjadi buku, tahap keempat implementasi melalui uji validitas ahli media dan kelompok kecil, dan tahap kelima evaluasi perbaikan hasil uji coba. Berdasarkan kelima tahap tersebut, dapat disimpulkan bahwa pengembangan buku ajar di Universitas Muhammadiyah Purworejo perlu dilakukan untuk meningkatkan kualitas dan mutu pendidikan.
\end{abstract}

Kata kunci: Bela Negara, Bahan Ajar, Apresiasi Puisi

\section{A. PENDAHULUAN}

Kesadaran terhadap sikap bela negara menjadi bagian penting dari strategi nasional bangsa dan negara Indonesia untuk menghadapi berbagai ancaman, gangguan, hambatan, dan tantangan. Indonesia sedang memasuki era revolusi Industri 4.0, ancaman terhadap negara menjadi lebih besar. Dengan demikian, sikap bela negara pun harus ditingkatkan. Hal ini sejalan dengan pendapat Malik (2017:35) salah satu solusi yang dianggap signifikan untuk pencegahan konflik di Indonesia adalah program bela Negara, yaitu suatu program yang di design sedemikian rupa sehingga bisa diterima oleh seluruh kalangan di Indonesia.

Bela negara adalah suatu sikap dan perilaku yang dimiliki warga negara untuk mempertahankan eksistensi negara. Andriyanto (2015:28) menerangkan bahwa bela negara adalah sikap yang dimiliki warga negara yang dilandasi sikap cinta tanah air Indonesia. Lebih lanjut, Marsekal Pertama TNI Bambang Eko sebagai Kepala Biro Hukum Setjen Kemenhan (2017:21), menjelaskan bahwa bela negara merupakan suatu strategi pertahanan negara yang harus dilakukan sesuai ketentuan peraturan perundang-undangan sebagai salah satu strategi 
dalam menanggulangi berbagai ancaman ideologi, keutuhan bangsa dan wilayah Negara Kesatuan Republik Indonesia.

Kesadaran akan sikap bela negara diamanatkan dalam UUD 1945 pasal 27 ayat 3, "bahwa setiap warga negara berhak dan wajib ikut serta dalam upaya pembelaan negara". Selanjutnya, dalam Pasal 30 ayat (1) UndangUndang Dasar Republik Indonesia tahun 1945, berbunyi "Tiap-tiap Warga negara berhak dan wajib ikut serta dalam usaha pertahanan dan keamanan negara dan“. Penjabaran lebih lanjut tentang pembelaan negara tertuang dalam Undang-Undang Republik Indonesia Nomor 3 Tahun 2002 tentang Pertahanan Negara Pasal 9, yang menyebutkan bahwa bela negara adalah sikap dan perilaku warga negara yang dijiwai oleh kecintaannya kepada NKRI yang berdasarkan Pancasila dan Undang-Undang Dasar (UUD) 1945 dalam menjamin kelangsungan hidup bangsa dan negara. Berdasarkan kedua amanat UUD tersebut, maka setiap warga negara wajib membela negara, sebab sikap ini berfungsi untuk membangun dan meningkatkan rasa cinta tanah air negara republik Indonesia, menegakkan negara republik Indonesia, tujuan nasional, serta mempertahankan dasar negara republik Indonesia.

Negara Indonesia harus selalu siaga, meskipun sudah merdeka sejak tanggal 17 Agustus 1945. Kesiapsiagaan tersebut perlu dilakukan, sebab meskipun sudah merdeka ancaman dari sudut non militer masih ada. Banyak ancaman yang terjadi, seperti: kedaulatan negara, keutuhan wilayah dan keselamatan segenap bangsa dari segala. Ferjana, Bambang, dan Sandra (2017:1) bahwa kesiapsiagaan bela negara merupakan aktualisasi nilai-nilai bela negara dalam kehidupan bermasyarakat, berbangsa dan bernegara sesuai peran dan profesi warga negara, demi menjaga kedaulatan negara, keutuhan wilayah dan keselamatan segenap bangsa dari segala bentuk ancaman yang pada hakikatnya mendasari proses nation and character building.

Meskipun masih banyak ancaman dari sudut non milter, tetapi kesadaran rakyat akan sikap bela negara mulai pudar. Beberapa peristiwa yang menunjukkan pudarnya sikap bela negara antara lain: sikap keluarga dan lingkungan sekitar yang tidak mencerminkan rasa nasionalisme, maraknya unjuk rasa, telah menimbulkan frustasi di kalangan pemuda dan hilangnya optimism sehingga yang ada hanya sifat malas, egois dan, emosional, para pemuda tidak bangga lagi menjadi bangsa Indonesia dan justru merasa bangga ketika menggunakan produk luar negeri, para pemuda kini dikuasai oleh narkoba dan minum-minuman keras sehingga sangat merusak martabat bangsa Indonesia, dan para pemuda meniru paham 
libelarisme, seperti sikap individualisme yang hanya memikirkan dirinya sendiri tanpa memperhatikan keadaan sekitar dan sikap acuh tak acuh pada pemerintahan.

Melihat kondisi demikian, tentu saja peran civitas akademika untuk ikut andil dalam menanamkan nilai-nilai bela negara bagi bangsa Indonesia kepada para generasi muda sangat penting. Peran pendidik dalam mengembangankan pembelajaran, media ajar, dan seumber belajar menjadi cara untuk menanamkan nilai-nilai bela negara dalam konteks pembelajaran. Pembelajaran adalah proses interaksi yang berlangsung antara berbagai faktor (multiple factor), ataupun komponen: guru, siswa, metode, sarana, dan media (Yasin, 2012: 3).

Pengembangan bahan ajar berbasis nilai bela negara merupakan salah satu cara yang ditempuh pendidik dalam mengintegrasikanya dalam pembelajaran. Dengan bahan ajar, berbasis nilai bela negara tersebut diharapkan pembelajaran yang dilaksanakan dapat meninkatkan kualitas emosional, sosial, intelektual, dan spiritual. Bahan ajar apresiasi ini sangat efektif untuk mrningkatkan aspek-aspek kualitas tersebut, sebab materi yang ada dalam bahan ajar tidak sekadar yang berkaitan dengan capaian pembelajaran. Akan tetapi, terintegrasi dengan nilai-nilai bela negara seperti cinta tanah air, pantang menyerah, rela berkorban, dll. Adapun tujuan penelitian untuk mendeskripsikan: pengembangan bahan ajar apresiasi puisi berbasis nilai bela negara bagi mahasiswa semester III Pendidikan Bahasa dan Sastra Indonesia di Universitas Muhammadiyah Purworejo dan efektivitas pembelajaran puisi berbasisi bahan ajar berbasisi nilai bela negara bagi mahasiswa semester III Pendidikan Bahasa dan Sastra Indonesia di Universitas Muhammadiyah Purworejo.

\section{B. KAJIAN TEORI}

Penyusunan buku ajar hendaknya memperhatikan beberapa tolok ukur agar menjadi buku ajar yang baik. Kusrianto dan Yuwono (2015:3-4), menyatakan bahwa syarat buku ada lima poin: (a) gaya bahasa semi formal, (b) struktur kalimat SPOK, (c) mencantumkan TIU, TIK, dan Kompetensi, (c) disusun berdasarkan rencana pembeelajaran, (d) mencantumkan teori pakar, (d) menggunakan rujukan, dan (e) mengakomodasi ide-ide baru. Bahan ajar berbasis bela negara sebagai produk penelitian ini, telah sesuai dengan tolok ukur di atas. Salah satu, tolok ukur tersebut adalah intergrasi nilai-nilai bela negara dalam materi bahan ajar.

Andrianto (2015:28) menjelaskan bela negara adalah suatu sikap dan tindakan warga negara untuk berbakti pada negara dan membela negara. Ciri-ciri bela negara menurut (Andriyanto, 2015: 109-110), antara lain : cinta tanah air, sadar berbangsa Indonesia, sadar bernegara Indonesia, berkeyakian akan kesaktian Pancasila sebagai Ideologi negara, rela 
berkorban untuk bangsa dan negara, memiliki kemampuan awal bela negara (secara psikis memiliki sifat mental, ulet, kerja keras, taat pada undang-undang, percaya diri, tahan uji, dan pantang menyerah, sedangkan seecara fisik memiliki sehat jasmani rohani).

\section{METODE PEMBELAJARAN}

Desain penelitian ini adalah Research and Development. Sujadi menjelaskann Research and Development adalah suatu langkah-langkah dalam mengembangkan suatu produk baru (Alfianaika, 2016: 158). Melalui penelitian pengembangan, peneliti mengembangkan suatu produk bahan ajar Apresiasi Puisi berbasis nilai bela negara. Penelitian dan pengembangan ini mengacu pada model ADDIE. Rozalena dan Sri (2016: 137) menyatakan bahwa model ADDIE adalah menciptakan suatu program yang efektif dan efesien sebagai sebuah proses yang integral. Tahapan model ADDIE antara lain: analysis, design, develop, implement, dan evaluation (Sutanti dan Edi, 2017: 15-16).

\section{PEMBAHASAN}

Pengembangan bahan ajar Apresiasi Puisi berbasis bela negara yang efektif bagi mahasiswa Pendidikan Bahasa dan Sastra Indonesia adalah bahan ajar dengan menerapkan tolok ukur sistem penulisan buku ajar. Tolok ukur tersebut, antara lain: (a) gaya bahasa formal, (b) struktur kalimat SPOK, (c) mencantumkan TIU, TIK, dan Kompetensi, (c) disusun berdasarkan rencana pembeelajaran, (d) mencantumkan teori pakar, (d) menggunakan rujukan, dan (e) mengakomodasi ide-ide baru. Peneliti dalam mengembangkan buku ini pun, didasarkan dengan tolok ukur di atas bahkan diintegrasikan dengan nilai bela negara, baik dalam teori, soal, penilaian, dan kinerja mahasiswa.

Selanjutnya, dalam pengembangan bahan ajar Apresiasi Puisi berbasis Nilai Bela Negara menggunakan konsep Addie. Pengunaan konsep ini dalam pengembangan buku ajar ini agar buku ajar yang dihasilkan efektif jika diterapkan dalam pembelajaran Apresiasi Puisi pada jurusan Pendidikan Bahasa dan Sastra Indonesia. Pengembangan bahan ajar Apresiasi Puisii berbasis Nilai Bela Negara ini dilakukan dalam lima tahapan sesuai dengan konsep Addie, meliputi : analyze, design, develop, implement, dan evaluate

Tahap pertama adalah analisis. Pada tahap ini peneliti melakukan analisis kebutuhan dan studi pustaka. Berdasarkan hasil observasi pertama diketahui bahwa kurikulum yang digunakan di Universitas Muhammadiyah Purworejo adalah Kurikulum berbasis Kerangka Kualifikasi Nasional Indonesia untuk semua semester. Tahap kedua adalah perencanaan. Dalam tahap ini peneliti telah memiliki rancangan produk yang akan dibuat, yaitu bahan ajar berupa buku ajar Apresiasi Pusi berbasis bela negara yang disusun berdasarkan Rencana 
Pembelajaran Semester. Rencana Pembelajaran Semester sesuai format yang telah disusun tim Lembaga Penjamin Mutu. Kemudian peneliti melanjutkan untuk menyusun materi Apresiasi Puisi, instrumen penilaian bahan ajar untuk melakukan validasi, instrumen untuk mengukur motivasi mahasiswa, soal pretest dan posttest. Selanjutnya, sebelum buku ajar diujicobakan kepada mahasiswa maka terlebih dahulu perlu dilakukan validasi buku ajar oleh validator yang terdiri dari satu orang ahli materi, satu orang ahli desain bahan ajar, dua orang doseni, dan kelompok kecil subjek pengguna yaitu enam mahasiswa semester III.

Tahap ketiga adalah pengembangan produk awal. Pada tahap ini peneliti mulai menyusun buku ajar Apresiasi Puisi berbasis bela negara yang terdiri dari beberapa fitur yaitu cover, kata pengantar, karakteristik buku ajar, daftar isi, cover bab, uraian materi, daftar pustaka, glosarium, indeks, dan biodata penulis. Tahap keempat adalah implementasi. Pada tahap ini, buku ajar yang telah disusun selanjutnya diuji validitasnya oleh satu ahli materi dan kelompok kecil Hasil dari uji coba lapangan awal ini berupa data kuantitatif dan kualitatif. Data kuantitatif yang diperoleh dari ahli media dan kelompok kecil mahasiswa berurut-urut sebesar $75 \%$ dan $83,3 \%$. Secara keseluruhan penilaian buku ajar dalam uji coba lapangan awal ini masuk dalam kategori valid atau layak digunakan dengan persentase rata-rata sebesar $88,92 \%$.

Data kualitatif berupa komentar dan saran yang digunakan sebagai bahan pertimbangan dalam melakukan revisi produk disajikan pada tabel berikut:

Tabel 4 Ringkasan Data Kualitatif Hasil Validasi Ahli Materi, Dua Desain Bahan Ajar, Dua dosen dan Kelompok Kecil Siswa

\begin{tabular}{|c|c|c|}
\hline No & Namuka & Komentar/ saran/ harapan \\
\hline 1. & $\begin{array}{l}\text { Ahli Media } \\
\text { (Prof. Dr. Sukirno, } \\
\text { M.Pd.) }\end{array}$ & $\begin{array}{l}\text { a. Kelengkapan unsur isi buku: perlu diperluas } \\
\text { b. Ruang lingkup dan kedalaman pembahasan: perlu } \\
\text { diperdalam } \\
\text { c. Kecukupan dan kemutakhiran data/informasi: perlu } \\
\text { penambahan referensi } \\
\text { d. Bahasa yang digunakan: perlu penataan tata tulis dan } \\
\text { ketepatan EYD }\end{array}$ \\
\hline \multirow[t]{5}{*}{2.} & Kelompok Kecil & \\
\hline & a. Halimah & $\begin{array}{l}\text { Harapan saya untuk buku ajar berbasis nilai bela negara } \\
\text { yaitu mampu dipahami dengan jelas, menambah } \\
\text { pengetahuan bagi peserta didik mengenai unsur bela } \\
\text { negara. }\end{array}$ \\
\hline & b. Sendy Claura & $\begin{array}{l}\text { Harapan saya, semoga buku ajar berbasis nilai bela negara } \\
\text { ini dapat bermanfaat bagi saya pribadi dan bangsa serta } \\
\text { mampu membuat kitalebih mengenal nilai-nilai luhur } \\
\text { bangsa serta menegakkan keadilan. }\end{array}$ \\
\hline & c. Yuni Wulan Sari & $\begin{array}{l}\text { Buku ini sudah bagus dan jelas gambarnya. Kertasnya } \\
\text { perlu menggunakan A4. Harapan saya perlu contoh } \\
\text { tentang apresiasi puisi. }\end{array}$ \\
\hline & d. Dian M.N. & $\begin{array}{l}\text { Semoga buku ajar ini dapat membantu mahasiswa dalam } \\
\text { memahami materi dan menambah pengetahuan tentang }\end{array}$ \\
\hline
\end{tabular}




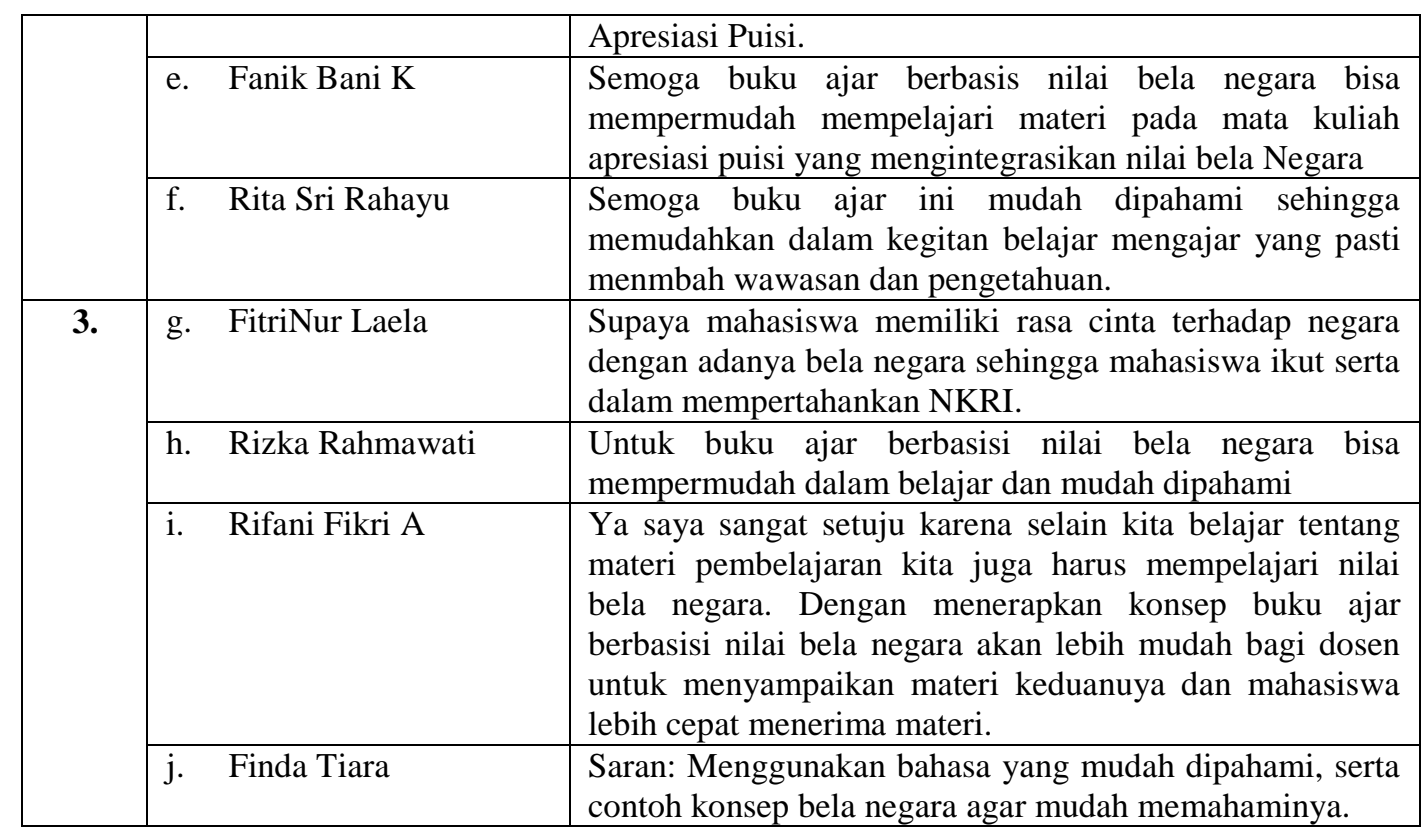

Tahap kelima adalah evaluasi. Tahap evaluasi ini bertujuan untuk mengetahui keberhasilan proses pembelajaran. Pada tahap ini yang menjadi rujukan dalam melakukan revisi adalah hasil uji coba. Menurut komentar dan saran dari ahli media dan mahasiswa. Menurut ahli media bahan ajar yang disusun dibutuhkan perluasan materi, pendalaman ruang lingkup, penambahan referensi, penataan tata tulis dan EY. Sementara itu, menurut para mahasiswa bahasa kurang dapat dipahami serta perlu perbaikan baik dari segi subtansi, kertas dan bahasaanya. Dari segi subtansi perlu ditambah contoh konsep bela negara. Dari segi kertas diharapkan penggunaan kertas A4. Dari segi bahasanya perlu menggunakan bahasa yang mudah dipahami. Sementara berdasarkan harapan dari beberapa validator, buku ajar sangat diharapkan untuk memahami konsep nilai bela negara serta dalam pembelajaranya. Berdasarkan saran dan harapan tersebut, peneliti melakukan refisi terhadap buku ajar dengan memperbaiki kualitas bahasa. Sementara, untuk subtansi tidak diberi contoh dan kertas disesuaikan dengan format tempelate penerbit. Penggunaan bahan ajar apresiasi puisi dalam pembelajaran memiliki pengaruh positif terhadap peningkatan mengapresiasi puisi. Hal ini diketahui dari pemerolehan peningkatan nilai rata-rata mahasiswa. Pada pembelajaran sebelum menggunakan bahan ajar apresiasi puisi berbasis nilai bela negara, skor rata-rata yang diperoleh mahasiswa adalah 54. Sementara itu, pada pembelajaran sesudah menggunakan bahan ajar apresiasi puisi berbasis nilai bela negara adalah 74,8. Peningkatan pembelajaran sebelum dan sesudah menggunakan bahan ajar apresiasi puisi sebesar 20,8 poin. Peningkatan tersebut dapat dilihat melalui diagram di bawah ini. 


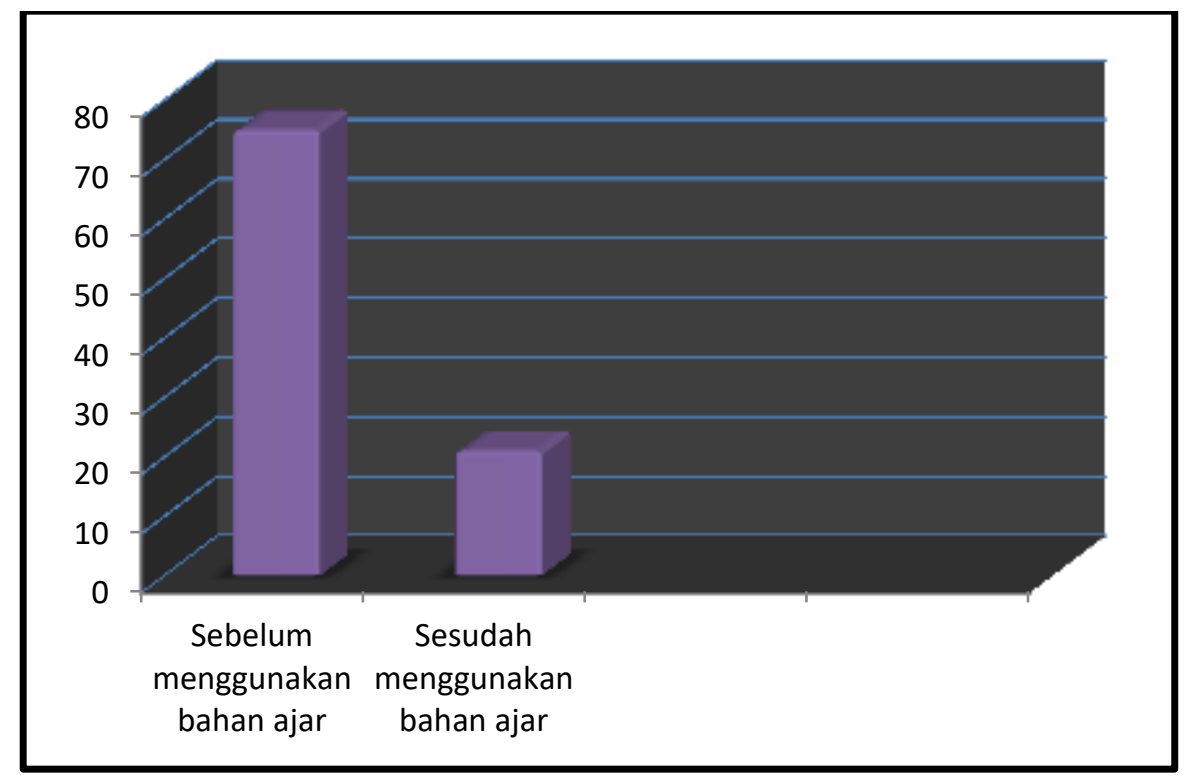

Diagram 1 Peningkatan Pembelajaran Menggunakan Bahan Ajar

Apresiasi Puisi Berbasis Nilai Bela Negara

Berdasarkan diagram di atas dapat dilihat bahwa nilai rata-rata mahasiswa terus meningkat. Peningkatan nilai rata-rata mahasiswa dalam menulis pidato mengapresiasi puisi juga terlihat pada setiap aspek soal. Berikut ini dipaparkan nilai rata-rata mahasiswa dalam mengapresiasi puisi pada setiap aspek dari pembelajaran sebelum dan sesudah menggunakan bahan ajar.

Tabel 2 Nilai Rata-Rata Mahasiswa dalam Mengapresiasi Puisi

\begin{tabular}{|l|l|l|l|}
\hline No & Aspek soal & Sebelum & Sesudah \\
\hline 1 & Soal 1 & 14 & 16 \\
\hline 2 & Soal 2 & 10 & 15 \\
\hline 3 & Soal 3 & 10 & 14 \\
\hline 4 & Soal 4 & 10 & 15 \\
\hline 5 & Soal 5 & 10 & 15 \\
\hline Jumlah & 54 & 75 \\
\hline \multicolumn{2}{|l|}{ Rata-rata } & 11 & 15 \\
\hline
\end{tabular}

Peningkatan skor pada setiap aspek mengapresiasi puisi sebelum dan sesudah menggunakan bahan ajar dapat digambarkan dalam diagram batang. Berikut adalah diagram batang peningkatan kemampuan siswa dari seluruh aspek. 


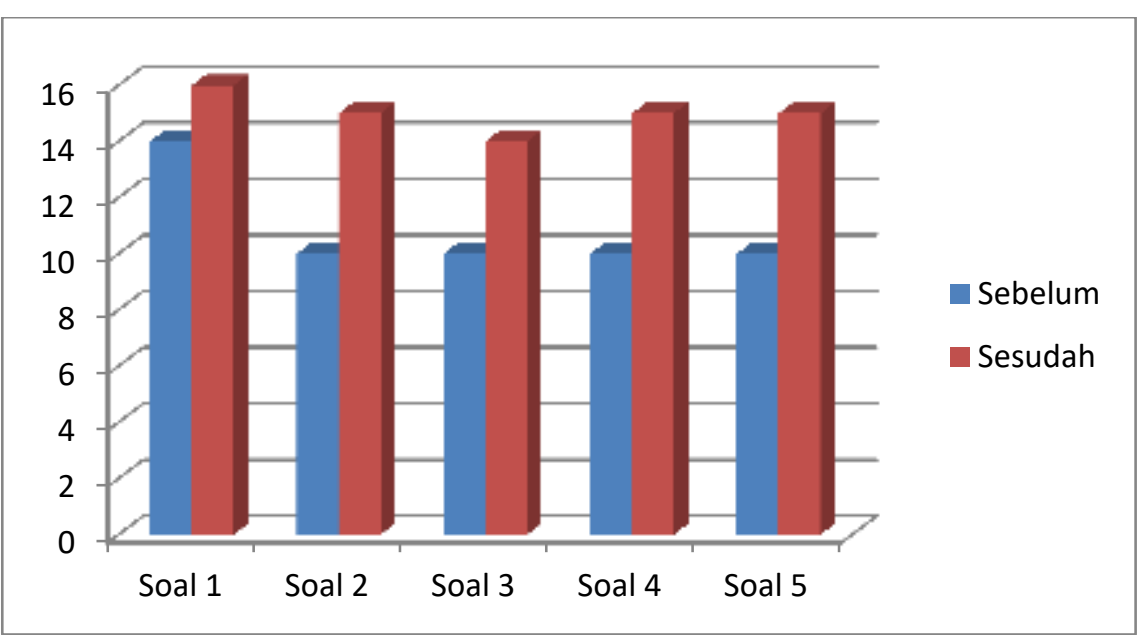

Diagram 2. Peningkatan Kemampuan Siswa

Berdasarkan gambar diagram di atas, terlihat bahwa nilai mahasiswa dalam mengapresiasi puisi pada setiap aspek penilaian mengalami peningkatan. Hal tersebut dipengaruhi oleh perbedaan pemanfaatan bahan ajar. Dengan demikian, pemanfaatan bahan ajar dalam pembelajaran sangat mempengaruhi pembelajaran.

\section{E. SIMPULAN DAN SARAN}

Berdasarkan hasil analisis di atas, dapat disimpulkan bahwa sebagian besar mahasiswa belum mempunyai buku ajar Apresiasi Puisi, mahasiswa juga membutuhkan buku Apresiasi Puisi berbasis nilai bela negara, dan rata-rata mereka setuju jika dosen mengembangkan buku ajar Apresiasi Puisi berbasis negara. Pemanfaatan bahan ajar ini dalam pembelajaran apresiasi sangat memperngaruhi. Hal tersebut nampak pada perbedaan hasil yang signifikan ketika dilakukan tes. Dengan, hasil demikian peneliti akan mengembangkan buku ajar apresiasi puisi berbasis bela negara sebagai wujud implementasi nilai bela negara di jenjang Universitas. Saran dalam penelitian ini yaitu memberikan inovasi baru mengenai variasi bahan ajar, dan diharapkan bahan ajar ini dapat digunakan untuk pembelajaran bahasa Indonesia di seluruh tingkat pendidikan.

\section{F. DAFTAR PUSTAKA}

Alfianika, Ninit. 2016. Metode Pnelitian Pengajaran Bahasa Indonesia. Yogyakarta: Depublish.

Andriyanto, Tuhana Taufik. 2015. Paradigma Baru Bela Negara. Yogyakarta : Global Pustaka Utama. 
Depdiknas. 2001. Kepmen Nomor:36/D/O/2001, Pasal 5, ayat 9(a) tentang Buku Ajar. Jakarta.

Ferrijana, Sammy, Bambang Suhartono, dan Sandra Erwanto. 2017. "Pelatihan Dasar Calon PNS Kesiapsiagaan Bela Negara". Modul. Jakarta: LAN.

Malik, Ichsan. 2017. "Bela Negara dan Penanganan Konflik". Media Informasi Kementrian Pertahanan WIRA, 35-42.

S, Eko Bambang. 2017. "Bela Negara dalam Perspektif Peraturan Perundang-undangan di Indonesia". Media Informasi Kementrian Pertahanan WIRA, 21-28.

Kusrianto, Adi dan Yuwono Marta Dinata. 2015. Microsoft Word untuk Buku Ajar. Jakarta: PT Elex Media.

Rozalena, Agustin, dan Siti Komala Sari. 2016. Panduan Praktis Menyusun Pengembangan Karir dan Pelatihan Karyawan. Jakarta: Raih Asa Sukses.

Sutanti, Tatik dam Edi Irawan. Kiat Sukses Meraih Hibah Penelitian Pengembangan. Yogyakarta: Depublish Publisher.

Undang-undang Dasar Negara Republik Indonesia Pasal 27 Ayat 1 Tahun 1945 Tentang Upaya Bela Negara.

Undang-undang Dasar Negara Republik Indonesia Pasal 27 Ayat 3 Tentang Hak dan Kewajiban Bela Negara.

Undang-undang Dasar Negara Republik Indonesia Pasal 30 Ayat 1 Tentang Pertahanan dan Keamanan Negara.

Yasin, Salechudin. 2012. "Metode Belajar dan Pembelajaran yang Efektif”. Jurnal Adabiyah, XII (1), 1-9. 